\title{
Aloperine attenuates hydrogen peroxide-induced injury via anti-apoptotic activity and suppression of the nuclear factor- $\kappa B$ signaling pathway
}

\author{
DONGLIANG REN*, WEISONG MA*, BAOZHEN GUO and SHUNYI WANG \\ Department of Orthopedics, The First Central Hospital of Baoding, Baoding, Hebei 071000, P.R. China
}

Received May 12, 2015; Accepted July 26, 2016

DOI: $10.3892 /$ etm.2016.3962

\begin{abstract}
Aloperine is an alkaloid that exerts significant inhibitive effects on acute inflammation and Type III and IV hypersensitivity caused by a variety of inflammatory agents. The aims of the present study were to investigate whether the protective effect of aloperine attenuates hydrogen peroxide $\left(\mathrm{H}_{2} \mathrm{O}_{2}\right)$-induced injury, and to identify the underlying mechanisms involved. Nucleus pulposus cells were extracted from adult male Sprague-Dawley rats, and incubated with fresh medium containing $200 \mu \mathrm{M} \mathrm{H}_{2} \mathrm{O}_{2}$ for $24 \mathrm{~h}$. In the study, treatment with aloperine significantly increased cell viability and suppressed apoptosis in $\mathrm{H}_{2} \mathrm{O}_{2}$-treated nucleus pulposus cells in a dose-dependent manner. In addition, 10 and $100 \mathrm{nM}$ aloperine significantly inhibited $\mathrm{H}_{2} \mathrm{O}_{2}$-induced tumor necrosis factor- $\alpha$ and interleukin- 6 activities, and significantly increased the $\mathrm{H}_{2} \mathrm{O}_{2}$-reduced superoxide dismutase and glutathione peroxidase activities in nucleus pulposus cells (all $\mathrm{P}<0.01)$. However, aloperine treatment $(10$ and $100 \mathrm{nM})$ significantly reduced the $\mathrm{H}_{2} \mathrm{O}_{2}$-induced caspase- 9 activity in nucleus pulposus cells. Furthermore, addition of 10 and $100 \mathrm{nM}$ aloperine significantly suppressed nuclear factor- $\kappa \mathrm{B}$ $(\mathrm{NF}-\kappa \mathrm{B})$ and phosphorylated-protein kinase B expression levels in $\mathrm{H}_{2} \mathrm{O}_{2}$-treated nucleus pulposus cells. In conclusion, the protective effect of aloperine attenuated $\mathrm{H}_{2} \mathrm{O}_{2}$-induced injury via hyperproliferation, its anti-apoptotic activity and suppression of the NF- $\mathrm{B}$ signaling pathway.
\end{abstract}

\section{Introduction}

Intervertebral disc degeneration is characterized by a reduced number and impaired function of intervertebral disc cells,

Correspondence to: Professor Shunyi Wang, Department of Orthopedics, The First Central Hospital of Baoding, 320 Changcheng North Road, Baoding, Hebei 071000, P.R. China

E-mail: wang1358208@163.com

*Contributed equally

Key words: aloperine, hydrogen peroxide-induced nucleus pulposus cell, anti-apoptotic, nuclear factor- $\mathrm{\kappa} B$ and manifests as nucleus dehydration, decreased proteoglycan content, particularly in aggregation states, and changes in collagen type and distribution (1). These changes weaken or remove the tension and pressure on intervertebral discs, and the changes in histology eventually results in changes of intervertebral disc biomechanics (1). Therefore, it is evident that a decrease in the number of active cells in intervertebral discs will result in the reduction in the synthesis of extracellular matrix and alterations in the cell composition $(2,3)$. This is the pathological basis of intervertebral disc degeneration, and excessive apoptosis is the direct cause of the decrease in intervertebral disc cells $(2,3)$.

Apoptosis serves an important role in the development of the body, as well as in a number of physiological and pathological processes (3). It has been suggested that apoptosis may be involved in the pathophysiologic changes experienced during intervertebral disc tissue degeneration, and it is noted that apoptosis serves an important role in the intervertebral disc degeneration process (4). Excessive apoptosis of intervertebral disc cells results in the reduction of active cells, $\mathrm{s}$ well as changes of cell composition, which is the pathological basis of intervertebral disc degeneration (5). However, studies have demonstrated that oxidative stress resulting from reactive oxygen species is the primary cause of apoptosis (6).

Reactive oxygen species include superoxide anion, hydrogen peroxide and hydroxyl radicals. Various antioxidant defense mechanisms exist in vivo, including antioxidant enzymes, such as superoxide dismutase (SOD) and catalase (3-5). When these defense mechanisms cannot prevent the generation of excessive reactive oxygen species, oxidative stress will occur, which causes the degeneration of cells or protein tissue, lipid oxidation, DNA damage and other physiological dysfunctional processes, leading to apoptosis (7). However, only a limited number of studies have focused on intervertebral disc degeneration and the apoptosis of nucleus pulposus cells due to oxidative stress (8-10).

Aloperine is a novel type of alkaloid drug with a significant inhibitory effect on acute inflammation, Type III and IV hypersensitivity, and adjuvant arthritis caused by multiple proinflammatory agents (11). The chemical structure of aloperine is presented in Fig. 1. Aloperine is a herb that has been found to have significant inhibitory effects on $T$ cells and $B$ cells, and on the production of interleukin (IL)-2 according to preliminary results (12). 
In the present study, hydrogen peroxide $\left(\mathrm{H}_{2} \mathrm{O}_{2}\right)$ was used as a stimulus to study the effect of oxidative stress on nucleus pulposus cell injury and underlying mechanisms (8). The study determined that the protective effect of aloperine attenuates $\mathrm{H}_{2} \mathrm{O}_{2}$-induced injury via its activation of AKT and suppression of the nuclear factor- $\kappa \mathrm{B}(\mathrm{NF}-\mathrm{\kappa B})$ pathway.

\section{Materials and methods}

Compounds. Dulbecco's modified Eagle's medium/Ham's F-12 medium (DMEM/F-12) and fetal bovine serum (FBS) were acquired from Hyclone (GE Healthcare Life Sciences, Little Chalfont, UK). Collagenase II (0.2\%; C0014) was purchased from Sunshine Biotechnology (Nanjing) Co., Ltd. (Nanjing, China). 3-(4,5-dimethylthiazol-2-yl)-2,5-diphenyltetrazolium bromide (MTT; ST316) was purchased from Beyotime Institute of Biotechnology (Haimen, China). Tumor necrosis factor- $\alpha$ (TNF- $\alpha$; R019), IL-6 (R016), SOD (A001-3) and glutathione peroxidase (GSH-Px; A005) commercial kits were purchased from Nanjing Jiancheng Bioengineering Institute (Nanjing, China). Aloperine (purity, $>99 \%$ ) was acquired from Yanchi Dushun Biological and Chemical Co., Ltd. (Ningxia, China).

Experimental animals and cell culture. Ethical approval for this study was provided by the Animal Ethical and Welfare Committee of Hebei Province (approval no. Hb14-3012). Adult male Sprague-Dawley rats ( $\mathrm{n}=24,9-10$ weeks), weighing $250 \pm 30 \mathrm{~g}$, were obtained from the Animal Resource Center of the First Central Hospital of Baoding (Baoding, China). They were housed at $22-23^{\circ} \mathrm{C}$ with $55-60 \%$ humidity and a 12:00/12:00 light/dark cycle. The rats were euthanized by an overdose of pentobarbital [100 mg/kg body weight; Sunshine Biotechnology (Nanjing) Co., Ltd.]. The spinal column was removed at the L1-L6 lumbar intervertebral discs, and then the gel-like nucleus pulposus was separated from the samples under aseptic conditions. The nucleus pulposus tissue samples were immediately placed into DMEM/F-12 and FBS, and were digested with $0.01 \%$ trypsin (Beyotime Institute of Biotechnology) at $37^{\circ} \mathrm{C}$ for $0.5-1 \mathrm{~h}$. The trypsin was absorbed and removed, and the nucleus pulposus tissue samples were washed with phosphate-buffered saline (PBS) and digested with $0.2 \%$ collagenase II at $37^{\circ} \mathrm{C}$ for $4 \mathrm{~h}$. Following digestion, nucleus pulposus cells were harvested using a $200 \mu \mathrm{m}$ mesh strainer. Next, the cells $\left(1 \times 10^{7}\right.$ cells) were seeded into a new culture bottle and incubated with DMEM/F-12 and 10\% FBS containing $1 \%$ penicillin/streptomycin (Sigma-Aldrich; Merck Millipore, Darmstadt, Germany) in a humidified atmosphere at $37^{\circ} \mathrm{C}$ and $5 \% \mathrm{CO}_{2}$. Subsequent to incubation, nucleus pulposus cells were washed with PBS.

Cell viability determined by MTT assay. Nucleus pulposus cells $\left(5 \times 10^{3}\right.$ cells/well) were seeded into a 96 -well plate, and incubated with fresh medium containing $200 \mu \mathrm{M} \mathrm{H}_{2} \mathrm{O}_{2}$ alone or with aloperine $(0.1-1,000 \mu \mathrm{M})$ for $24 \mathrm{~h}$. After incubation, $10 \mu 1$ MTT was added into each well and incubated in a humidified atmosphere at $37^{\circ} \mathrm{C}$ and $5 \% \mathrm{CO}_{2}$. Subsequently, $150 \mu \mathrm{l}$ dimethyl sulfoxide was added to each well and agitated for $20 \mathrm{~min}$. The absorbance was measured using Labsystems Multiskan MS plate Reader (Synergy2; BioTek Instruments, Inc., Winooski, VT, USA) at $540 \mathrm{~nm}$.

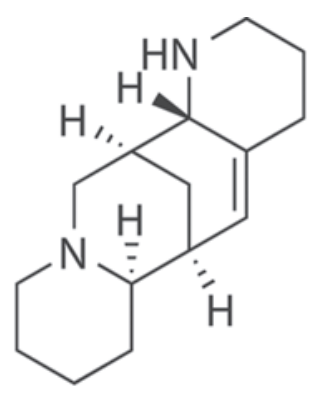

Figure 1. Chemical structure of aloperine.

Cell apoptosis determined by flow cytometry. Nucleus pulposus cells $\left(2 \times 10^{6}\right.$ cells/well) were seeded into a 6 -well plate and incubated with fresh medium containing $200 \mu \mathrm{M} \mathrm{H}_{2} \mathrm{O}_{2}$ alone or with aloperine (1, 10 and $100 \mathrm{nM}$ ) for $24 \mathrm{~h}$. Following incubation, nucleus pulposus cells were washed twice with cold PBS and incubated with $500 \mu \mathrm{l}$ binding buffer (BestBio, Shanghai, China). Subsequently, $5 \mu 1$ Annexin V-FITC and $5 \mu \mathrm{l}$ propidium iodide (BestBio) were added and the cells were incubated for $30 \mathrm{~min}$ at $4^{\circ} \mathrm{C}$ in the dark. Cell apoptosis was analyzed on a FACScan flow cytometer (BD Biosciences, San Jose, CA, USA) with CellQuest software (BD Biosciences).

Determination of inflammation and oxidation activity. Nucleus pulposus cells $\left(5 \times 10^{3}\right.$ cells/well) were seeded into a 96-well plate, and incubated with fresh medium containing $200 \mu \mathrm{M} \mathrm{H}_{2} \mathrm{O}_{2}$ alone or plus aloperine (1, 10 and $100 \mathrm{nM}$ ) for $24 \mathrm{~h}$. After incubation, TNF- $\alpha$, IL-6, SOD and GSH-Px were measured using commercial ELISA kits according to the manufacturer's instructions and a Labsystems Multiskan MS Plate Reader was used to measure the absorbance at $450 \mathrm{~nm}$.

Measurement of caspase- 9 activity. Nucleus pulposus cells $\left(2 \times 10^{6}\right.$ cells/well) were seeded into a 6 -well plate, and incubated with fresh medium containing $200 \mu \mathrm{M} \mathrm{H}_{2} \mathrm{O}_{2}$ alone or with aloperine (1, 10 and $100 \mathrm{nM}$ ) for $24 \mathrm{~h}$. Subsequently, nucleus pulposus cells were incubated with $100 \mu 1$ tissue lysis buffer (Beyotime Institute of Biotechnology) for $30 \mathrm{~min}$ on ice. Homogenates were centrifuged at $12,000 \times \mathrm{g}$ for $10 \mathrm{~min}$ at $4^{\circ} \mathrm{C}$ and the supernatant was collected to assess the protein concentration using a BCA assay kit, according to the manufacturer's protocol (KeyGen Biotech Co., Ltd., Nanjing, China). Equal protein $(10 \mathrm{mg})$ was incubated with substrate (Ac-DEVD-pNA-caspase-9; BestBio) for $2 \mathrm{~h}$ in the dark at room temperature. The absorbance was then measured using a Labsystems Multiskan MS plate reader at $405 \mathrm{~nm}$.

Western blot analysis of $N F-\kappa B$ and phosphorylated AKT ( $p$-AKT) levels. Nucleus pulposus cells $\left(2 \times 10^{6}\right.$ cells/well $)$ were seeded into a 6 -well plate, and incubated with fresh medium containing $200 \mu \mathrm{M} \mathrm{H}_{2} \mathrm{O}_{2}$ alone or with aloperine (1, 10 and $100 \mathrm{nM}$ ) for $24 \mathrm{~h}$. Next, the cells were incubated with $100 \mu \mathrm{l}$ tissue lysis buffer for $30 \mathrm{~min}$ on ice. Homogenates were centrifuged at $12,000 \times \mathrm{g}$ for $10 \mathrm{~min}$ at $4^{\circ} \mathrm{C}$ and the supernatant was collected to assess the protein concentration using a BCA kit, according to the manufacturer's protocol. Equal protein $(50-60 \mathrm{mg}$ ) was separated with $8-12 \%$ sodium dodecyl sulfate-polyacrylamide gel electrophoresis and transferred 


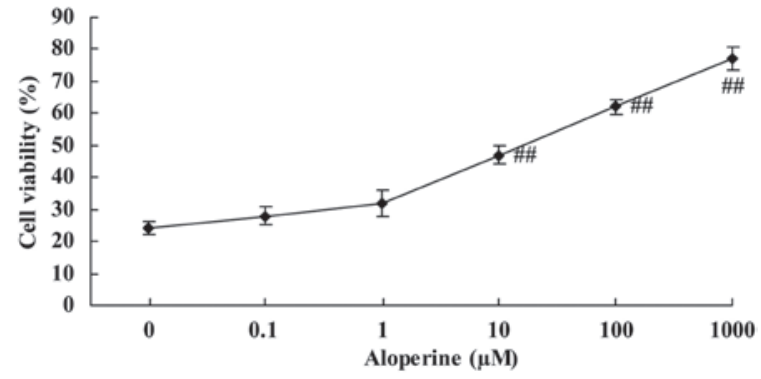

Figure 2. Cell viability of $\mathrm{H}_{2} \mathrm{O}_{2}$-induced cells following treatment with various concentrations of aloperine, as determined by MTT assay. ${ }^{\# \#} \mathrm{P}<0.01$ vs. $0 \mathrm{nM}$ aloperine.

onto a nitrocellulose membrane using an electroblotting apparatus. The nitrocellulose membrane was incubated with anti-NF-kB (sc-8008, 1:500), anti-p-AKT (sc-7985; 1:1,000) and anti-AKT (sc-8312; 1,1,000) antibodies all from Santa Cruz Biotechnology, Inc. (Dallas, TX, USA) overnight at $4^{\circ} \mathrm{C}$. Subsequently, the nitrocellulose membrane was incubated with the appropriate horseradish peroxidase (HRP)-conjugated $\operatorname{IgG}$ secondary antibody (sc-358915, sc-2008; 1:5000; Santa Cruz Biotechnology, Inc.) followed by incubation with an enhanced chemiluminescence substrate. The relative quantity of each protein was measured using AlphaEase FC (FluorChem FC2) software (ProteinSimple, Santa Clara, CA, USA).

Statistical analysis. Statistical analysis was performed using SPSS version 18.0 software (SPSS, Inc., Chicago, IL, USA) and data are presented as the mean \pm standard deviation from at least three experiments. Comparisons between two groups were performed using Student's t-test. $\mathrm{P}<0.05$ was considered to indicate a statistically significant difference.

\section{Results}

Aloperine increases the viability of $\mathrm{H}_{2} \mathrm{O}_{2}$-treated nucleus pulposus cells. Treatment of nucleus pulposus cells with $\mathrm{H}_{2} \mathrm{O}_{2}$ alone ( $0 \mathrm{nM}$ aloperine) resulted in low cell viability, as determined by MTT assay. However, aloperine $(0.1-1,000 \mu \mathrm{M})$ promoted the cell viability of $\mathrm{H}_{2} \mathrm{O}_{2}$-treated nucleus pulposus cells in a concentration-dependent manner. In particular, aloperine significantly increased the cell viability of $\mathrm{H}_{2} \mathrm{O}_{2}$-treated nucleus pulposus cells at doses of 10,100 and $1,000 \mu \mathrm{M}(\mathrm{P}<0.01$; Fig. 2).

Aloperine suppresses $\mathrm{H}_{2} \mathrm{O}_{2}$-induced apoptosis. The effects of aloperine on $\mathrm{H}_{2} \mathrm{O}_{2}$-induced apoptosis in nucleus pulposus cells were determined using flow cytometry. Treatment with 10 and $100 \mathrm{nM}$ aloperine significantly suppressed the $\mathrm{H}_{2} \mathrm{O}_{2}$-induced apoptosis $(\mathrm{P}<0.01$; Fig. 3$)$.

Aloperine decreases $\mathrm{H}_{2} \mathrm{O}_{2}$-induced caspase-9 activity. In nucleus pulposus cells, the caspase- 9 activity in the $\mathrm{H}_{2} \mathrm{O}_{2}$ model group was significantly increased compared with that in the control group $(\mathrm{P}<0.01)$. Compared with the $\mathrm{H}_{2} \mathrm{O}_{2}$ model group, the caspase- 9 activity was significantly decreased by 10 and $100 \mathrm{nM}$ aloperine in $\mathrm{H}_{2} \mathrm{O}_{2}$-induced nucleus pulposus cells $(\mathrm{P}<0.01$; Fig. 4).

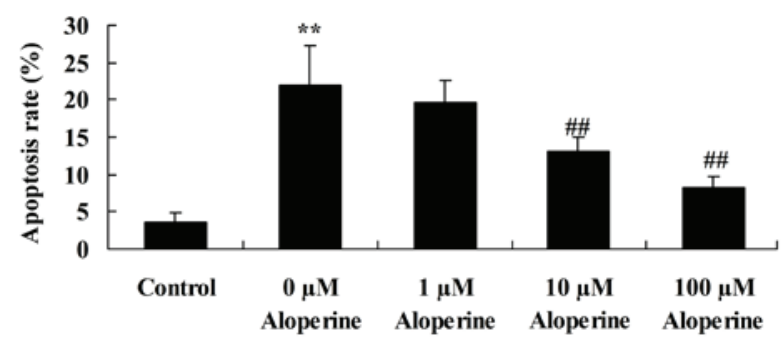

Figure 3. Apoptosis rate of $\mathrm{H}_{2} \mathrm{O}_{2}$-induced cells following treatment with various concentrations of aloperine, as determined by flow cytometric analysis. ${ }^{* *} \mathrm{P}<0.01$ vs. the control group; ${ }^{\# \#} \mathrm{P}<0.01$ vs. $0 \mathrm{nM}$ aloperine.

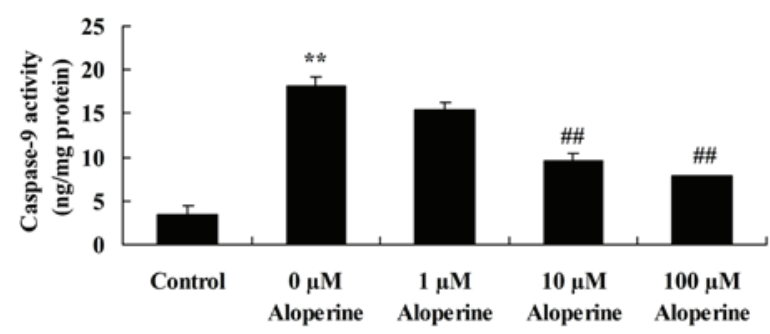

Figure 4. Caspase-9 activity levels in $\mathrm{H}_{2} \mathrm{O}_{2}$-induced cells following treatment with various concentrations of aloperine. ${ }^{* *} \mathrm{P}<0.01$ vs. the control group; ${ }^{\# \#} \mathrm{P}<0.01$ vs. $0 \mathrm{nM}$ aloperine.

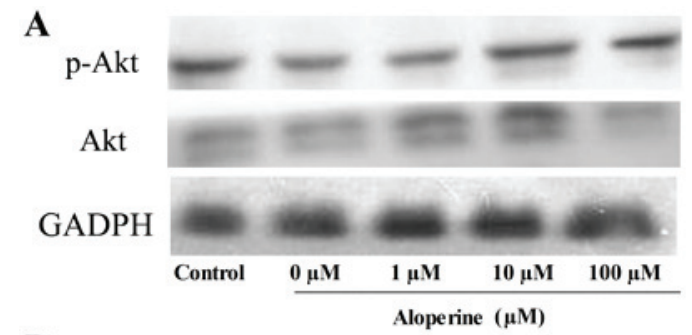

B

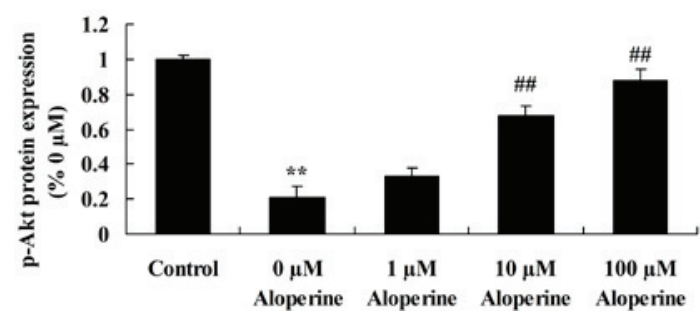

Figure 5. p-AKT protein expression in $\mathrm{H}_{2} \mathrm{O}_{2}$-induced cells following treatment with various concentrations of aloperine. The protective effect of aloperine on $\mathrm{p}-\mathrm{AKT}$ protein expression by (A) western blotting assays and (B) statistical analysis of p-AKT protein expression. ${ }^{* *} \mathrm{P}<0.01 \mathrm{vs}$. the control group; ${ }^{\# \#} \mathrm{P}<0.01$ vs. $0 \mathrm{nM}$ aloperine. p-AKT, phosphorylated-AKT.

Effect of aloperine on p-AKT expression in $\mathrm{H}_{2} \mathrm{O}_{2}$-treated nucleus pulposus cells. To examine the mechanism of action of aloperine on $\mathrm{H}_{2} \mathrm{O}_{2}$-induced cell apoptosis in nucleus pulposus cells, p-AKT expression was analyzed using western blotting. The p-Akt expression of the $\mathrm{H}_{2} \mathrm{O}_{2}$ model group was reduced compared with that of the control group $(\mathrm{P}<0.01)$. p-AKT was significantly upregulated upon treatment with 10 and $100 \mathrm{nM}$ aloperine in $\mathrm{H}_{2} \mathrm{O}_{2}$-treated nucleus pulposus cells, compared with the $\mathrm{H}_{2} \mathrm{O}_{2}$ alone treatment group ( $\mathrm{P}<0.01$; Fig. 5). 

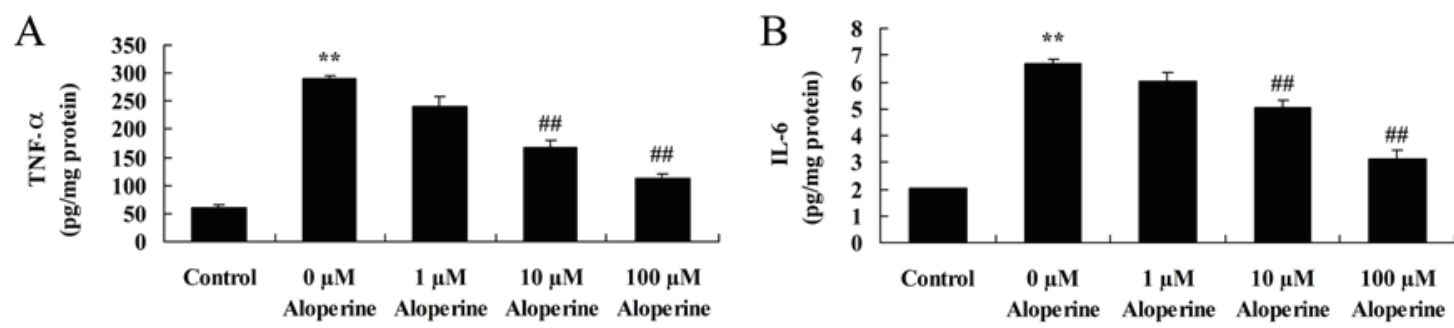

Figure 6. (A) TNF- $\alpha$ and (B) IL-6 protein expression levels in $\mathrm{H}_{2} \mathrm{O}_{2}$-induced cells treated with aloperine. A dose-dependent inhibitory effect of aloperine is observed. ${ }^{* *} \mathrm{P}<0.01$ vs. the control group; ${ }^{\# \#} \mathrm{P}<0.01$ vs. $0 \mathrm{nM}$ aloperine. TNF- $\alpha$, tumor necrosis factor- $\alpha$; IL- 6 , interleukin-6.
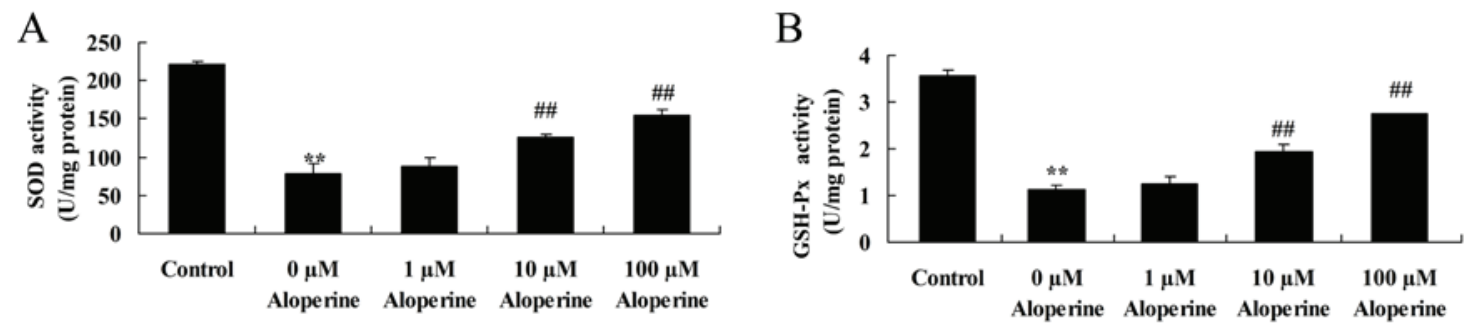

Figure 7. Oxidation activity in $\mathrm{H}_{2} \mathrm{O}_{2}$-induced cells treated with aloperine. A protective effect of aloperine on $\mathrm{H}_{2} \mathrm{O}_{2}$-inhibited (A) SOD and (B) GSH-Px activities is observed. ${ }^{* *} \mathrm{P}<0.01$ vs. the control group; ${ }^{\# /} \mathrm{P}<0.01$ vs. $0 \mathrm{nM}$ aloperine. SOD, superoxide dismutase; GSH-Px, glutathione peroxidase.

A

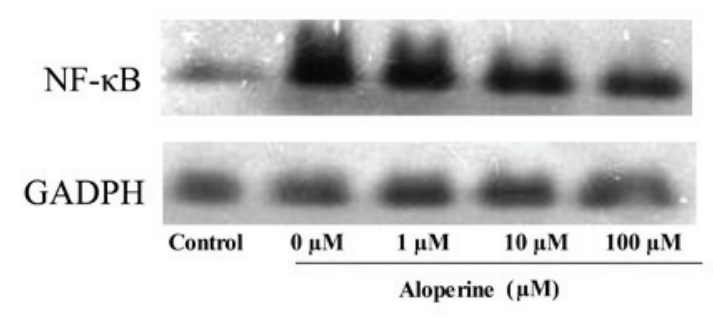

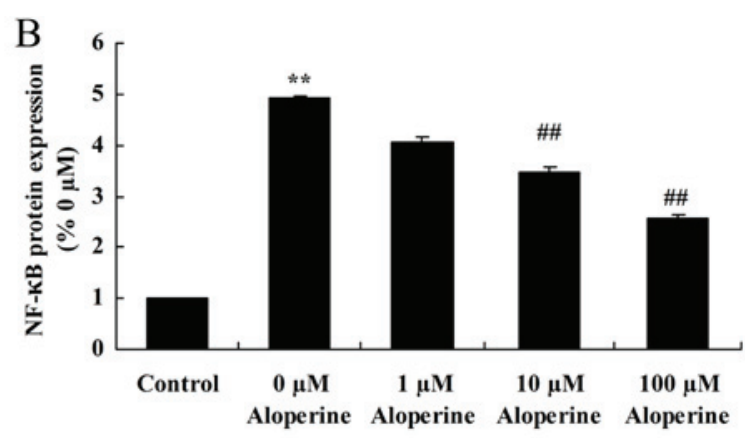

Figure 8. NF- $\mathrm{KB}$ protein expression in $\mathrm{H}_{2} \mathrm{O}_{2}$-induced cells treated with aloperine, as shown in (A) western blots and (B) quantified levels. A dose-dependent inhibitory effect of aloperine on NF- $\kappa \mathrm{B}$ expression is observed. ${ }^{* *} \mathrm{P}<0.01$ vs. the control group; ${ }^{\# \#} \mathrm{P}<0.01 \mathrm{vs}$. $0 \mathrm{nM}$ aloperine. NF- $\kappa \mathrm{B}$, nuclear factor- $\kappa \mathrm{B}$.

Aloperine reduces TNF- $\alpha$ and IL- 6 expression levels in $\mathrm{H}_{2} \mathrm{O}_{2}$-treated cells. $\mathrm{H}_{2} \mathrm{O}_{2}$ significantly increased TNF- $\alpha$ and IL-6 levels in nucleus pulposus cells $(\mathrm{P}<0.01)$. Treatment with 10 and $100 \mathrm{nM}$ aloperine was found to significantly inhibit the expression levels of TNF- $\alpha$ and IL-6 compared with those in the cells treated only with $\mathrm{H}_{2} \mathrm{O}_{2}(\mathrm{P}<0.01$; Fig. 6).

Effect of aloperine on $\mathrm{H}_{2} \mathrm{O}_{2}$-induced oxidation activity. The effect of aloperine on the SOD and GSH-Px activities in $\mathrm{H}_{2} \mathrm{O}_{2}$-treated nucleus pulposus cells is presented in Fig. 7 . $\mathrm{H}_{2} \mathrm{O}_{2}$ significantly inhibited SOD and GSH-Px activities in the model group compared with the control group $(\mathrm{P}<0.01)$. Following treatment with 10 and $100 \mathrm{nM}$ aloperine, there were significant increases in the SOD and GSH-Px activities in nucleus pulposus cells compared with those in the cells treated only with $\mathrm{H}_{2} \mathrm{O}_{2}(\mathrm{P}<0.01$; Fig. 7).

Effect of aloperine on $\mathrm{H}_{2} \mathrm{O}_{2}$-induced $\mathrm{NF}-\kappa \mathrm{B}$ protein expression. To determine the protective mechanism of aloperine against $\mathrm{H}_{2} \mathrm{O}_{2}$-induced inflammation in nucleus pulposus cells,
$\mathrm{NF}-\kappa \mathrm{B}$ protein expression levels were analyzed using western blotting. The results showed that NF-kB protein expression of model group was higher than that of control group (Fig 8). Treatment with 10 and $100 \mathrm{nM}$ aloperine significantly inhibited NF- $\mathrm{KB}$ protein expression in $\mathrm{H}_{2} \mathrm{O}_{2}$-induced nucleus pulposus cells compared with the expression in cells treated with $\mathrm{H}_{2} \mathrm{O}_{2}$ alone ( $\mathrm{P}<0.01$; Fig. 8).

\section{Discussion}

Intervertebral disc degeneration is considered to be closely associated with apoptosis of nucleus pulposus cells (1). Although numerous studies have investigated apoptosis, few studies have examined how oxidative stress results in nucleus pulposus cell apoptosis and intervertebral disc degeneration $(10,13,14)$. Therefore, the current study used $\mathrm{H}_{2} \mathrm{O}_{2}$ to establish an oxidative stress model in nucleus pulposus cells in order to identify the underlying mechanisms (15). In addition, the current study aimed to explore the role of apoptosis in intervertebral disc degeneration, and to clarify the signal transduction pathway 
involved in intervertebral disc apoptosis, which may help to achieve the prevention of intervertebral disc degeneration by interfering with apoptosis (15). Following the primary culture of rat nucleus pulposus cells, $200 \mu \mathrm{M} \mathrm{H}_{2} \mathrm{O}_{2}$ was used to stimulate the cells for $24 \mathrm{~h} . \mathrm{H}_{2} \mathrm{O}_{2}$ treatment resulted in significant apoptosis, which confirms that oxidative stress can lead to apoptosis (16). In the present study, it was demonstrated that treatment with aloperine significantly increased cell viability and inhibited cell apoptosis of $\mathrm{H}_{2} \mathrm{O}_{2}$-treated nucleus pulposus cells in a dose-dependent manner.

Caspase exists in cells as an inactive zymogen form, and becomes an active fragment following proteolytic processing, and thus is used in the investigation of cell apoptosis (17). In neuronal apoptosis induced by various stimuli, caspase acts as a modulating agent (18). With increasing doses of $\mathrm{H}_{2} \mathrm{O}_{2}$, the expression of caspase-9 is increased (19). The caspase family serves an important role in the process of mediating apoptosis, in which caspase-9 is a critical executioner molecule, acting in numerous apoptosis signaling transduction pathways (20). In the current study, aloperine treatment significantly suppressed the $\mathrm{H}_{2} \mathrm{O}_{2}$-induced caspase-9 activity of nucleus pulposus cells via the upregulation of the AKT signaling pathway. Wang et al (21) suggested that aloperine exerts antitumor effects against multiple myeloma through the caspase-9/p-PTEN/p-AKT-dependent apoptotic pathways.

$\mathrm{NF}-\kappa \mathrm{B}$ is a protein with multidirectional transcriptional regulation functions, which is widely distributed, adjusts the transcriptional regulation of numerous genes and is involved in a number of important physiological and pathological processes, such as inflammatory reactions, the immune response, cell proliferation, transformation and apoptosis (22). The most common form of $\mathrm{NF}-\kappa \mathrm{B}$ is a heterodimer consisting of two protein subunits, P50 and RelA/P65. It has been demonstrated that an increase in $\mathrm{H}_{2} \mathrm{O}_{2}$ concentration, which is known to induce apoptosis, results in increased NF- $\kappa \mathrm{B}$ P65 expression and activity (23). The results of the present study suggest that treatment with aloperine significantly reduced TNF- $\alpha$ and IL-6 activities, and enhanced SOD and GSH-Px activities in $\mathrm{H}_{2} \mathrm{O}_{2}$-treated nucleus pulposus cells through the downregulation of the NF- $\kappa \mathrm{B}$ signaling pathway. Zhou et al (24) reported that the anti-inflammatory and anti-oxidative action of aloperine significantly inhibited the effects of allergic reactions. In addition, $\mathrm{Xu}$ et al (25) demonstrated that administration of aloperine attenuated neuropathic pain through its anti-oxidation activity and suppression of the NF- $\kappa \mathrm{B}$ signaling pathway.

In the present study, aloperine increased the viability and inhibited the apoptosis of $\mathrm{H}_{2} \mathrm{O}_{2}$-treated nucleus pulposus cells in a dose-dependent manner. In addition, aloperine exerted anti-inflammatory, anti-oxidative and anti-apoptotic effects, upregulated p-AKT expression and downregulated the NF- $\mathrm{B}$ signaling pathway in $\mathrm{H}_{2} \mathrm{O}_{2}$-treated nucleus pulposus cells. In particular, aloperine at concentrations of 10 and $100 \mathrm{nM}$ exerted significant effects. In conclusion, aloperine attenuated $\mathrm{H}_{2} \mathrm{O}_{2}$-induced nucleus pulposus cell injury via anti-apoptotic activity and suppression of the NF- $\mathrm{KB}$ signaling pathway.

\section{References}

1. Wang HQ and Samartzis D: Clarifying the nomenclature of intervertebral disc degeneration and displacement: From bench to bedside. Int J Clin Exp Pathol 7: 1293-1298, 2014.
2. Liang QQ, Ding DF, Xi ZJ, Chen Y, Li CG, Liu SF, Lu S, Zhao YJ, Shi Q and Wang YJ: Protective effect of ligustrazine on lumbar intervertebral disc degeneration of rats induced by prolonged upright posture. Evid Based Complement Alternat Med 2014: 508461, 2014.

3. Presciutti SM, Paglia DN, Karukonda T, Soung do Y, Guzzo R, Drissi $\mathrm{H}$ and Moss IL: PDGF-BB inhibits intervertebral disc cell apoptosis in vitro. J Orthop Res 32: 1181-1188, 2014.

4. Reihani Kermani H, Pourghazi M and Mahani SE: Effects of pulsed electromagnetic field on intervertebral disc cell apoptosis in rats. Electromagn Biol Med 33: 246-249, 2014.

5. Ariga K, Yonenobu K, Nakase T, Hosono N, Okuda S, Meng W, Tamura Y and Yoshikawa H: Mechanical stress-induced apoptosis of endplate chondrocytes in organ-cultured mouse intervertebral discs: An ex vivo study. Spine (Phila Pa 1976) 28: 1528-1533, 2003.

6. Heyde CE, Tschoeke SK, Hellmuth M, Hostmann A, Ertel W and Oberholzer A: Trauma induces apoptosis in human thoracolumbar intervertebral discs. BMC Clin Pathol 6: 5, 2006.

7. Gruber HE, Watts JA, Hoelscher GL, Bethea SF, Ingram JA, Zinchenko NS and Hanley EN Jr: Mitochondrial gene expression in the human annulus: In vivo data from annulus cells and selectively harvested senescent annulus cells. Spine J 11: 782-791, 2011.

8. Yang L, Rong Z, Zeng M, Cao Y, Gong X, Lin L, Chen Y, Cao W, Zhu L and Dong W: Pyrroloquinoline quinone protects nucleus pulposus cells from hydrogen peroxide-induced apoptosis by inhibiting the mitochondria-mediated pathway. Eur Spine J 24: 1702-1710, 2015.

9. Chu H, Yu H, Ren D, Zhu K and Huang H: Plumbagin exerts protective effects in nucleus pulposus cells by attenuating hydrogen peroxide-induced oxidative stress, inflammation and apoptosis through $\mathrm{NF}-\kappa \mathrm{B}$ and Nrf-2. Int J Mol Med 37: 1669-1676, 2016.

10. Chen J, Hou C, Chen X, Wang D, Yang P, He X, Zhou J and Li H: Protective effect of cannabidiol on hydrogen peroxide-induced apoptosis, inflammation and oxidative stress in nucleus pulposus cells. Mol Med Rep 14: 2321-2327, 2016.

11. Yuan XY, Ma HM, Li RZ, Wang RY, Liu W and Guo JY: Topical application of aloperine improves 2,4-dinitrofluorobenzene-induced atopic dermatitis-like skin lesions in $\mathrm{NC} / \mathrm{Nga}$ mice. Eur J Pharmacol 658: 263-269, 2011.

12. Yuan XY, Ma HM, Li RZ, Wang RY, Liu W and Guo JY: Topical application of aloperine improves 2,4-dinitrofluorobenzeneinduced atopic dermatitis-like skin lesions in NC/Nga mice. Eur J Pharmacol 658: 263-269, 2011.

13. Miao D and Zhang L: Leptin modulates the expression of catabolic genes in rat nucleus pulposus cells through the mitogen-activated protein kinase and Janus kinase 2/signal transducer and activator of transcription 3 pathways. Mol Med Rep 12: 1761-1768, 2015.

14. Chen JW, Ni BB, Li B, Yang YH, Jiang SD and Jiang LS: The responses of autophagy and apoptosis to oxidative stress in nucleus pulposus cells: implications for disc degeneration. Cell Physiol Biochem 34: 1175-1189, 2014.

15. Nerlich AG, Schleicher ED and Boos N: 1997 Volvo Award winner in basic science studies. Immunohistologic markers for age-related changes of human lumbar intervertebral discs. Spine (Phila Pa 1976) 22: 2781-2795, 1997.

16. Zhou X, Zhang HL, Gu GF, Ding Y, Jia JB, Fu QS and He SS: significant In Vitro Cell Dev Biol Anim 49: 279-286, 2013.

17. Park C, Jin CY, Kim GY, Jeong YK, Kim WJ and Choi YH: Induction of apoptosis by ethanol extract of Prunus mume in U937 human leukemia cells through activation of caspases. Oncol Rep 26: 987-993, 2011.

18. He Q, Bao L, Zimering J, Zan K, Zhang Z, Shi H, Zu J, Yang X, Hua F, Ye X and Cui G: The protective role of (-)-epigallocatechin-3-gallate in thrombin-induced neuronal cell apoptosis and JNK-MAPK activation. Neuroreport 26: 416-423, 2015.

19. Wu TT, Li LF, Du R, Jiang L and Zhu YQ: Hydrogen peroxide induces apoptosis in human dental pulp cells via caspase-9 dependent pathway. J Endod 39: 1151-1155, 2013.

20. Park WH: Anti-apoptotic effect of caspase inhibitors on $\mathrm{H}_{2} \mathrm{O}_{2}$-treated $\mathrm{HeLa}$ cells through early suppression of its oxidative stress. Oncol Rep 31: 2413-2421, 2014.

21. Wang H, Yang S, Zhou H, Sun M, Du L, Wei M, Luo M, Huang J, Deng H, Feng Y, et al: Aloperine executes antitumor effects against multiple myeloma through dual apoptotic mechanisms. J Hematol Oncol 8: 26, 2015.

22. Sun BZ, Chen L, Wu Q, Wang HL, Wei XB, Xiang YX and Zhang XM: Suppression of inflammatory response by flurbiprofen following focal cerebral ischemia involves the NF- $\kappa B$ signaling pathway. Int J Clin Exp Med 7: 3087-3095, 2014. 
23. Jia WC, Liu G, Zhang CD and Zhang SP: Formononetin attenuates hydrogen peroxide $\left(\mathrm{H}_{2} \mathrm{O}_{2}\right)$-induced apoptosis and $\mathrm{NF}-\kappa \mathrm{B}$ activation in RGC-5 cells. Eur Rev Med Pharmacol Sci 18: 2191-2197, 2014.

24. Zhou CC, Gao HB, Sun XB, Shi HB, Liu W, Yuan HN and Wang ZX: Anti-inflammatory and anti-allergic action of aloperine. Zhongguo Yao Li Xue Bao 10: 360-365, 1989 (In Chinese).
25. Xu YQ, Jin SJ, Liu N, Li YX, Zheng J, Ma L, Du J, Zhou R, Zhao CJ, Niu Y, et al: Aloperine attenuated neuropathic pain induced by chronic constriction injury via anti-oxidation activity and suppression of the nuclear factor kappa B pathway. Biochem Biophys Res Commun 451: 568-573, 2014. 